https://doi.org/10.18778/7525-969-8.28

\author{
Mirella Korzeniewska-Wiszniewska
}

\title{
Obraz relacji serbsko-boszniackich na przykładzie Sandżaku w pierwszej dekadzie XXI w.
}

Sandżak jest obszarem o powierzchni $8867 \mathrm{~km}^{2}$, położonym na terytorium Serbii oraz Czarnogóry, z czego na terytorium Serbii znajduje się 4504 km², na terytorium Czarnogóry zaś 3905 km². Sama nazwa została „odziedziczona” po istniejaccym w latach 1878-1913 Sandżaku Nowopazarskim, terytorialnej jednostce wyznaczonej przez Turków Osmańskich, której siedziba znajdowała się w głównym mieście Nowym Pazarze (pierwotnie nazwa Sandżak oznaczała flagę). Ponieważ słowo to pochodziło z języka tureckiego, Serbowie częstokroć używali wobec tego obszaru nazwy Raszka, podkreślając jego serbską przynależność, mimo iż tylko wschodnia jego część wchodziła w skład okręgu o tej nazwie ${ }^{1}$.

Według ostatnich danych statystycznych z roku 2002, w Sandżaku mieszkały w sumie 393223 osoby, z czego w części serbskiej 235 567, a czarnogórskiej 157656 osób². Również w tym spisie, po stronie serbskiej 136087 osób zadeklarowało się jako Boszniacy ${ }^{3}, 19503$ określiło się zaś jako Muzułmanie. Ta dwoistość nazwy wprowadza element komplikacji do rzeczywistej identyfikacji narodowej. Muzułmanie (jako grupa etniczna oraz religijna) zostali wyniesieni do rangi narodu w roku 1969, jeszcze w okresie rządów komunistycznych ${ }^{4}$. Josip Broz-Tito uznał za istotne pojawienie się kolejnego, relatywnie licznego narodu, dla złagodzenia napięć między Serbami a Chorwatami. W ten sposób przedstawiciele

${ }^{1}$ G. Bašić, Položaj Bošnjaka u Sandžaku, Beograd 2002, s. 12.

2 Ta liczba zmniejszyła się w stosunku do spisu z 1991 r., według którego terytorium Sandżaku zamieszkiwało 440 tys. osób, z czego Boszniacy stanowili 253 tys., a Serbowie i Czarnogórcy 187 tys. - zob. tamże, s. 14; Sandžak, [w:] Bošnjačko nacionalno vijeće, http://www.bnv.org.rs/ostalo/sandzak (dostęp 21 XI 2011).

${ }^{3}$ W języku serbskim Bošnjaci, w polskiej literaturze można spotkać spolszczoną nazwę Boszniacy.

${ }^{4}$ M.J. Zacharias, Komunizm - federacja - nacjonalizmy. System władzy w Jugosławii 1943-1991. Powstanie - przekształcenie - rozkład, Warszawa 2004, s. 257; G. Bašić, dz. cyt., s. 34; Bošnjaci, [w:] Bošnjačko nacionalno vijeće, http://www.bnv.org.rs/ostalo/bosnjaci (dostęp 21 XI 2011). 
społeczności muzułmańskiej, nie przynależący do żadnej innej grupy etnicznej tego wyznania ${ }^{5}$, zostali podniesieni do rangi narodu konstytutywnego o tej samej nazwie, co potwierdzała uchwalona w 1974 r. konstytucja.

Aż do 1993 r. naród ten funkcjonował pod nazwą Muzułmanie, Bośniakami (serb. Bosanac) określano zaś w ogóle osoby zamieszkujące obszar Bośni i Hercegowiny (BiH). W 1993 r., już podczas wojny w BiH, 28 września w Sarajewie odbył się Drugi Boszniacki Zjazd, podczas którego „powrócono do tradycyjnej nazwy narodowej Boszniak (Bošnjak)”'

Konsekwencją tego faktu było wprowadzenie wspomnianej nazwy do życia publicznego, języka służbowego i dokumentów. Słowo Boszniak miało oznaczać: „osobę narodowości boszniackiej, wyznania muzułmańskiego, która mówiła bośniackim językiem oraz pielęgnowała boszniacką kulturę i tradycję"7. Według założeń zjazdu z 1993 r. nazwa ta miała ,zostać przyjęta dla wszystkich przedstawicieli tego narodu na obszarze całej byłej Jugosławii i za granica"”. Problem pojawił się wówczas, gdy okazało się, że nie wszyscy Muzułmanie przyjęli tę nazwę i część z nich określała się, również w oficjalnych dokumentach, dotychczasowym mianem. Przykładem tego może być właśnie wspomniany spis z $2002 \mathrm{r}$. Aktualnie problem jest o tyle istotny, że Boszniacy stanowia najliczniejszą po Serbach i Węgrach grupę narodową w Republice Serbii, co daje im prawo do korzystania z przysługujących im praw mniejszościowych, łącznie z dążeniem do uzyskania autonomii terytorialnej, co zostanie opisane poniżej ${ }^{9}$.

${ }^{5}$ Powszechna była tendencja do uznawania ich za zislamizowanych Serbów bądź Chorwatów.

${ }^{6}$ G. Bašić, dz. cyt., s. 35; Bošnjaci...

7 Bošnjaci...

8 Tamże.

${ }^{9}$ Analizując spis przeprowadzony w Czarnogórze w roku 2003 można zauważyć, że na tamtejszym obszarze Sandżaku jeszcze mniej osób przyjęło nazwę narodową Boszniak (48 184). 24625 zadeklarowało się jako Muzułmanie (to daje im łączną sumę 72809 mieszkańców, co stanowi 11,77\% wszystkich mieszkańców Czarnogóry). Według informacji, które podaje oficjalna strona Boszniackiej Rady Narodowej są to „Boszniacy, którzy określili się jako Muzułmanie”. Związane jest to m.in. z faktem, iż na Zjeździe przyjęto, że macierzą wszystkich Boszniaków jest Bośnia i Hercegowina, co również napotkało opór także wśród samych zainteresowanych. To właśnie z tego powodu przedstawiciele omawianego narodu skupieni wokół Macierzy Muzułmanów w Czarnogórze pozostali przy wcześniejszej nazwie „Muzułmanin”. Jeszcze inna grupa, pochodząca głównie ze środowiska miejskiego, identyfikuje się jako „Czarnogórcy wyznania muzułmańskiego”. Wypracowanie wspólnej nazwy z pewnością będzie procesem długofalowym, który będzie wprowadzał różnego rodzaju komplikacje na płaszczyźnie nie tylko publiczno-urzędowej, ale i naukowej. W polskiej literaturze naukowej czy publicystyce również można zauważyć - zwłaszcza w latach ubiegłych - brak precyzji w stosowaniu nazwy Bośniak - Boszniak Muzułmanin, które to słowa są często stosowane zamiennie. G. Bašić, dz. cyt., s. 35. 
Sami przedstawiciele tego narodu pochodzący z obszaru Sandżaku chętnie podkreślali własną liczebność i w różnych źródłach można było znaleźć informacje, że w Bośni i Hercegowinie szacowano liczbę Boszniaków pochodzenia sandżackiego na ok. 160 tys.; w Słowenii i Chorwacji miało ich być ok. 40 tys., na terytorium Kosowa i Macedonii około 100 tys., na obszarze zaśs Bałkanów w ogóle ok. 530 tys. Poza tym regionem można było ich znaleźć w Turcji (gdzie miało żyć ok. 3,5 mln potomków sandżackich Boszniaków!), w Europie Zachodniej (gdzie liczbę szacowano na ponad 150 tys.) oraz „w innych krajach na całym świecie" ${ }^{”}$.

Kwestia boszniacka w Serbii pojawiła się w momencie rozpadu Socjalistycznej Federacyjnej Republiki Jugosławii (SFRJ) i związanej z nim wojny w Bośni i Hercegowinie w 1992 r. W tamtym czasie jednak niewiele rozmawiano na temat statusu tej mniejszości, a problemem zajmowała się właściwie tylko boszniacka Partia Akcji Demokratycznej (SDA) utworzona w Sandżaku pod przywództwem Sulejmana Ugljanina ${ }^{11}$. W momencie powstania „małej”, złożonej tylko z Serbii i Czarnogóry, Federacyjnej Republiki Jugosławii (FRJ) w kwietniu 1992 r., SDA z siedziba w Nowym Pazarze złożyła wniosek, w imieniu wszystkich Boszniaków, o przyznanie Sandżakowi autonomii terytorialnej. Oczywiście władze w Belgradzie odmówiły, gdyż obawiano się, że zmiany mogłyby ewoluować w stronę separatyzmu i kolejnego sporu terytorialnego, tym razem na obszarze samej Federacyjnej Republiki Jugosławii. Mimo to utworzona w maju 1991 r. Muzułmańska Narodowa Rada Sandżaku (Muslimansko nacionalno vijeće Sandžaka, MNVS) rozpisała w październiku 1992 r. referendum na temat powołania autonomii politycznej. Wzięło w nim udział 70,19\% uprawnionych do głosowania, z czego 98,929\% opowiedziało się za statusem autonomicznym, a $1,069 \%$ przeciwko ${ }^{12}$.

Na podstawie wyników referendum - nieuznanego przez władze belgradzkie - na konferencji pokojowej w sprawie byłej Jugosławii, która odbyła się w Londynie w dniach 26-28 sierpnia 1992 r., złożono wniosek o przyznanie Sandżakowi specjalnego statusu. Kolejnym krokiem było utworzenie programu, zawierającego postulaty sandżackich Boszniaków, które miały sprecyzować charakter autonomii, o jaką się ubiegali. Powstał on na początku czerwca 1993 r. i przedstawiał organizacje administracyjna i instytucjonalną obszaru według demokratycznych zasad, w myśl których utworzona zostałaby Skupsztina Sandżacka, gubernator, rząd oraz sądownictwo. Kompetencje tych władz rozciagałyby się na ,szkolnictwo, kulture, media, gospodarkę, ekonomię, kwestie energetyczne, w tym korzystanie z bogactw naturalnych, służbę zdrowia i ubezpieczenia socjalne, komunikację,

${ }_{10}$ Por. tami̇e, s. 20; Bošnjaci...

11 Wcześniej SDA powstała jako muzułmańska partia w Bośni i Hercegowinie pod przywództwem Aliji Izetbegovicia.

${ }^{12}$ G. Bašić, dz. cyt., s. 57. 
administrację, system bankowy, sądownictwo i policję"13. Zakres swobody w istocie byłby nawet większy od tego, jakim dysponowały republiki w Jugosławii. Wprawdzie podkreślano, że władze nie zajmowałyby się polityką zagraniczna i nawiązywaniem relacji, „oprócz współpracy naukowej, technicznej, kulturowej, oświatowej i ekonomicznej”"14. Taki zakres swobody był jednak nie do przyjęcia przez władze w Belgradzie, ponieważ oznaczał zbyt dużą niezależność regionu, grożącą dalszym rozpadem państwa.

Taka postawa Muzułmanów (Boszniaków) była konsekwencją odrodzenia nurtów narodowych, pod silnym wpływem religijnym, który pod koniec lat 80 . XX w. widoczny był przede wszystkim u Serbów i Chorwatów. Wyeksponowanie religii muzułmańskiej u Boszniaków nastapiło również w momencie tego odrodzenia i rozpadu Jugosławii, kiedy przynależność narodowa stała się kwestią niezwykle istotna, wykorzystywaną również w bezwzględny sposób w polityce przez głównych aktorów sceny politycznej. Jak podkreślała Aida Ćorović - dyrektorka pozarządowej organizacji Urban-In - na początku narodowego samookreślania u Boszniaków religijna tożsamość nie była jednoznacznie zdefiniowana. Wpływ na to miał charakter wojen i fakt, że muzułmanie byli w nich najczęstszymi ofiarami. To przyczyniło się zarówno do wypracowania odrębności społeczeństwa muzułmańskiego, jak i zwrócenia się ku religii islamskiej. Dla sandżackich Boszniaków kwestia narodowości połączona z muzułmańską obyczajowościa, przestrzeganie jej, stała się imperatywem egzystencji na obszarze państwa serbskiego. Ofiary, które ów naród poniósł podczas wojen w BiH, oraz wojenne wydarzenia były pojmowane w ogóle jako biblijna kara jaka dotknęła Sodomy i Gomory, spowodowana wcześniejszym odwróceniem się od wartości Koranu. Po 1995 r. sytuacja polityczna w Serbii, rządzonej wciąż przez ekipę Slobodana Miloševicia, nie zmieniła się, atmosfera napięcia i nieuregulowanych problemów etnicznych nie sprzyjała zaś stabilizacji społecznej. Zrodziło to jeszcze większe poczucie frustracji wśród społeczności boszniackiej, co jest odczuwalne do dnia dzisiejszego, a przejawia się m.in. poprzez „impotencję intelektualną” polityków pochodzących z regionu, którzy zamiast koncentrować się na poprawieniu jakości stosunków z Belgradem, pracowali tylko na rzecz zaspokojenia partykularnych interesów własnych lub partyjnych, o czym będzie mowa poniżej ${ }^{15}$.

13 Tamize, s. 59.

14 Tamże.

15 D. Gibas-Krzak, Bośnia i Hercegowina - upadek idei państwa multietnicznego na przełomie XX i XXI w. Zarys problemu, [w:] Bośnia i Hercegowina 15 lat po Dayton. Przeszłość - teraźniejszość - perspektywy. Studia i szkice, pod red. P. Chmielewskiego i S.L. Szczesio, Łódź 2011, s. 297-298; S. Novosel, Muftija Zukorlić ima ogromnu odgovornost za negativna dešavanja u Sandžaku, „Danas”, 18 II 2011, http://www.danas.rs/dodaci/ vikend/muftija_zukorlic_ima_ogromnu_odgovornost_za_negativna_desavanja_u_sandzaku.26.html?news_id=210022 (dostęp 20 XII 2011). 
W 1999 r. zostało przyjęte przez Boszniacką Radę Narodową Sandżaku (Bošnjačko nacionalno vijeće Sandžaka, BNVS) ${ }^{16}$ Memorandum o autonomii Sandżaku i specjalnych relacjach z Bośnią i Hercegowina, co zostało potraktowane jako kolejny krok w dążeniach tej mniejszości. Region został przedstawiony jako obszar multikulturowy, który wymaga instytucjonalizacji ochrony praw człowieka i obywatela wszystkich narodów konstytucyjnych ${ }^{17}$.

Gdy w 2000 r. Serbia obrała nowy, demokratyczny kurs, zorientowany na rzeczywistą integrację ze strukturami euroatlantyckimi, Boszniacy oraz BNVS poparli przemiany na scenie politycznej, uważając, że jest to szansa otworzenia zupełnie nowego rozdziału w relacjach z serbskimi władzami. Dlatego też w wyborach prezydenckich wsparli swymi głosami koalicję Demokratyczna Opozycja Serbii (Demokratska opozicija Srbije, DOS) i jej kandydata na prezydenta Vojislava Koštunicę - głównego oponenta S. Miloševicia (który stał na czele Serbii i „nowej” Jugosławii od ponad dekady), mobilizując wszystkich ziomków $\mathrm{z}$ terytorium państwa ${ }^{18}$.

Zmiany zainicjowane przez nowe władze po roku 2000 oznaczały również przyjęcie standardów europejskich w kwestii mniejszości narodowych i wprowadzenie prawodawstwa, które umożliwiłoby korzystanie, m.in. Boszniakom, z praw mniejszościowych. Sprawę jednak utrudniła likwidacja FRJ na rzecz federacji serbsko-czarnogórskiej w 2003 r. Mimo zachowania jednolitości terytorialnej państwa, drogi obu republik zaczęły się rozchodzić, w 2006 r. zaś Czarnogórcy w referendum zdecydowali się odłączyć od Serbów, tworząc osobny organizm państwowy według dotychczasowych granic republiki, co spowodowało podział obszaru Sandżaku między Serbię i Czarnogórę. Wydawało się, że fakt ten całkowicie przekreślił boszniackie dążenia do autonomii, jednak było to tylko tymczasowe zarzucenie idei. SDA i inne partie tamtego regionu, choć nie wszystkie, zaczęły w następnych latach dążyć do większej (mimo że jeszcze nie do końca sprecyzowanej) niezależności od Belgradu.

Nowe ustawodawstwo, dostosowujące kraj do standardów zachodnioeuropejskich, dotyczyło również kwestii mniejszościowych, które uregulowane zostały przez następujące akty prawne: Karta Narodów Zjednoczonych, Powszechna Deklaracja Praw Człowieka, Ramowa Konwencja o Ochronie Mniejszości Narodowych, Europejska Karta o Językach Narodowych i Regionalnych, Konstytucja Republiki Serbii z 2006 r., Ustawa o Ochronie Praw i Swobód Mniejszości Narodowych oraz Ustawa o Związkach Narodowych Mniejszości z 31 sierpnia 2009 r.

Konstytucja Republiki Serbii z 2006 r. była podstawowym aktem prawnym, który reguluje kwestie mniejszościowe w państwie, zapewniając ochronę integralności, poszanowanie praw mniejszości, zabraniając dyskryminacji i szerzenia

\footnotetext{
${ }_{16}$ BNVS powstała z przekształcenia MNVS.

17 G. Bašić, dz. cyt., s. 61 .

18 Tamże, s. 73.
} 
nienawiści rasowej, wyznaniowej i religijnej, prawo do pielęgnowania odrębności, a także zbiorowe prawa mniejszościowe w zakresie informacji, kultury, kształcenia i języka urzędowego. Ponadto konstytucja zabraniała przymusowej asymilacji, dawała prawo do stowarzyszania się i podejmowania współpracy z ziomkami mieszkajacymi w innych państwach ${ }^{19}$.

Zbiorowe prawa mniejszości realizowane były przez tzw. autonomię kulturalna, na którą składały się: prawo do korzystania z języka i pisma, kształcenie w języku ojczystym, prawo do korzystania z pisowni imion i nazwisk we własnym języku, tworzenie prywatnych instytucji kształcących. Tworzone mogły być również samorządy mniejszościowe, a konkretnie związki narodowe, które reprezentowały mniejszość na płaszczyźnie wspomnianych praw ${ }^{20}$.

W myśl przepisów o języku służbowym i pisowni, język urzędowy mniejszości narodowej obowiązywał w gminach, gdzie dana mniejszość stanowiła ponad 15\% ludności. Zgodnie z tym język bośniacki obowiązuje w trzech okręgach: Sjenicy, Tutinie i Nowym Pazarze ${ }^{21}$.

Jeśli zaś chodzi o regulacje prawne związane z kształceniem w językach mniejszości narodowych, to zagadnienie to regulowała Ustawa o podstawach systemu kształcenia i wychowania z roku 2004. W myśl jej przepisów przedstawiciele mniejszości narodowej mogli kształcić się w swoim języku lub też dwujęzycznie, w przypadku zaś, gdy kształcenie odbywało się w języku serbskim, możliwa była nauka języka ojczystego z elementami kultury narodowej ${ }^{22}$.

$\mathrm{Na}$ podstawie tego nowego ustawodawstwa 6 września $2003 \mathrm{r}$. odbyło się założycielskie posiedzenie Boszniackiej Rady Narodowej (Bošnjačko nacionalno vijeće, BNV) w Serbii i Czarnogórze. Ogłoszono tym samym zaprzestanie działalności BNVS oraz wygaśnięcie ważności dotychczasowych dokumentów, regulujących jej działalność. Przewodniczącym nowo utworzonego przedstawicielstwa pozostał S. Ugljanin, na czele Komitetu Wykonawczego stanął zaś Esad Džudžević. Ustalono również zasady wyborcze i zakres działalności nowej instytucji. Według statutu przyjętego 13 września tego samego roku BNV była „najwyższym ciałem przedstawicielskim boszniackiej wspólnoty narodowej w Serbii, w zakresie kontroli stosowania języka bośniackiego na płaszczyźnie służbowej, w piśmie, oświacie, kulturze i informacji”. Miała również osobowość prawną․

${ }_{19}$ Ustav Republike Srbije, s. 5 i n., http://www.ns.vi.jt.rs/images/dokumenti/dokumenti_pdf_lat/urs_lat.pdf(dostęp 3 IV 2012).

20 Tamize.

${ }^{21} \mathrm{~W}$ porównaniu z tym albański język ma status urzędowego w Preševie, Bujanovcu i Medveđi, bułgarski w Bosilegradzie i Dimitrovgradzie, w Serbii centralnej: bośniacki, albański i bułgarski, w Wojwodinie zaś ten status ma aż sześć języków: chorwacki, rumuński, rusiński, węgierski, słowacki i czeski, tamże, s. 5 i n.

${ }_{22}^{2}$ N. Gojković, Sistem zaštite manjina u Republici Srbiji, s. 9, http://www.kas.de/ upload/auslandshomepages/serbien/Gojkovic_pred.pdf.

${ }^{23}$ O nama, [w:] Bošnjačko nacionalno vijeće, http://www.bnv.org.rs/o-nama/ (dostęp 21 XI 2011). 
W odniesieniu do statutu BNV oraz praw mniejszości w Republice Serbii działalność Rady na przestrzeni lat 2003-2009 była oceniana pozytywnie zarówno pod względem uchwalania dokumentów regulujaccych aspekty życia boszniackiego $\mathrm{w}$ zakresie przewidzianym prawem ${ }^{24}$, jak i uczestnictwa w krajowych i zagranicznych konferencjach poświęconych problematyce mniejszościowej. Dnia 27 czerwca 2009 r. w Nowym Pazarze BNV uchwaliła Deklarację o położeniu sandżackich Boszniaków w Republice Serbii. „W dokumencie tym przedstawione zostały pryncypia dla lepszej i efektywniejszej realizacji praw narodowych Boszniaków sandżackich w Republice Serbii we wszystkich aspektach i obszarach życia społecznego" ${ }^{25}$.

Od lata 2010 r. Rada nie funkcjonuje tak jak wcześniej. Przyczyną był konflikt między politykami boszniackimi, który wygenerował spór na linii BNV - Belgrad. W lipcu 2010 r. doszło do wyborów do BNV, w których 17 na 35 miejsc zdobyła Boszniacka Wspólnota Kulturowa (Bošnjačka kulturna zajednica, BKZ) Muamera Zukorlicia ${ }^{26}, 13$ SDA S. Ugljanina, 5 zaś lista wyborcza o nazwie Boszniackie Odrodzenie (Bošnjački preporod), której liderem jest Rasim Ljajić. $\mathrm{Na}$ posiedzeniu założycielskim nie było wszystkich przedstawicieli, a jednak mimo braku kworum przeprowadzono głosowanie nad ukonstytuowaniem Rady i rozdzieleniem funkcji, z czym w praktyce nie zgadzali się nieobecni boszniaccy przedstawiciele. W związu z tym faktem władze państwowe nie uznały tego wyboru. Od tej pory, co jakiś czas, zostaje podawana do wiadomości publicznej data nowych wyborów (mimo funkcjonowania BNV pod przywództwem M. Zukorlicia), jednak wciąż się one nie odbyły. Uznanie lub jego brak przez przedstawicieli społeczności sandżackiej stał się jedną z głównych linii konfliktu między boszniackimi politykami27.

Latem 2010 r. BNV przyjęła Deklarację, na podstawie której została powołana Narodowa Rada Sandżaku (Narodnog vijeća Sandžaka, NVS). Jej działalność została zauważona jednak dopiero rok później, gdy na Wszechboszniackim Zgromadzeniu Sandżaku 11 września 2011 r. przyjęto Deklarację o Narodowej Radzie Sandżaku, w którą to Zgromadzenie przeobraziło się, stając się „największym organem przedstawicielskim obywateli Sandżaku". Na jego czele stanął Džemail Suljevićc ${ }^{28}$. Rada w założeniu miała być stałą instytucja, mającą swoje

${ }^{24} \mathrm{~W}$ ostatnim czasie były to uchwały o symbolach narodowych - godle i fladze, świętach narodowych, wyróżnieniach za wybitną działalność oraz o manifestacjach narodowych sandżackich Boszniaków. Tamże.

${ }_{25}$ Tamize.

${ }^{26}$ Jest on równocześnie przywódcą Wspólnoty Islamskiej w Serbii, podlegającej Wspólnocie Islamskiej w Bośni i Hercegowinie.

27 S. Biševac, Bojkot, naravno, „Danas”, 18 I 2011, http://www.danas.rs/danasrs/kolumnisti/bojkot_naravno.888.html?news_id=207931 (dostęp 2 II 2012).

28 S. Novosel, Mogući i građanski protesti, „Danas”, 15 IX 2011, http://www.danas.rs/ dodaci/sandzak/moguci_i_gradjanski_protesti.42.html?news_id=223701 (dostęp 20 III 2012). 
przedstawicielstwa za granica (Sarajewo, Gôteborg, Nowy Jork, a w perspektywie Bruksela, Waszyngton, Istambuł). Wiceprzewodniczacymi zostali Admir Muratović i Hazbija Kalač, sekretarzem Hedija Škrijelj, przewodniczącym Komitetu Wykonawczego Sead Šaćirović, pozostałymi zaś członkami NVS stali się członkowie nieuznawanego przez Belgrad BNV, a także organizacje i instytucje powiązane ze Wspólnotą Islamską w Serbii M. Zukorlicia.

We wrześniu 2011 r. NVS przyjęła Deklarację o Dyskryminacji w Sandżaku, w której zostały wymienione płaszczyzny dyskryminacji, a także środki, które należało podjać w celu jej likwidacji. Chodziło głównie o działalność instytucji (również międzynarodowych) w celu ochrony praw mniejszości; z kolei Boszniacka Akademia Nauk i Umiejętności (Bošnjačka akademija nauka $i$ umjetnosti, BANU) miała opracować program przetrwania mniejszości boszniackiej w państwie serbskim. Gdyby te środki nie spowodowały żadnych zmian, należało zaczaćc przygotowywać obywateli do protestów w formie obywatelskiego nieposłuszeństwa i manifestacji ${ }^{29}$.

Jeżeli chodzi o samą Deklarację, to warto przyjrzeć się jej treści bardziej szczegółowo. Według niej dyskryminacja mniejszości boszniackiej odbywała się - najbardziej ogólnie rzecz ujmując - w formie terroru państwowego. Ataki na Wspólnotę Islamską w Serbii, naukę islamu czy wręcz prawosławizowanie muzułmańskich dzieci były kolejnymi zarzutami wymienionymi w dokumencie, które miały świadczyć, że postępowanie władz w Belgradzie było skierowane na „eksterminację" tej mniejszości. Do kolejnych należały: niejasności i spory wokół muzułmańskiej własności, obstrukcja działalności BNV, akredytacja Uniwersytetu Międzynarodowego, nierównomierna reprezentacja mniejszościowa w organach państwowych oraz ekonomiczna i medialna dyskryminacja ${ }^{30}$.

Konflikt z władzami w Belgradzie, a także wśród samej społeczności boszniackiej, obrazowała również sytuacja związana z istnieniem i funkcjonowaniem wspólnot muzułmańskich. W 1993 r. powstała Wspólnota Islamska w Serbii (Islamska zajednica u Srbiji), jako odrębny mešihat (jednostka administracyjna), podporządkowany Wspólnocie Islamskiej w Bośni i Hercegowinie. Aktualnie dzieli ona Republikę Serbii na cztery muftijstva: sandżacki, preszewski, nowosadski oraz belgradzki. Na czele Wspólnoty stoi wielki mufti M. Zukorlić. Drugą instytucją jest Wspólnota Islamska Serbii (Islamska zajednica Srbije) na czele z reis-ul-ulemem Ademem Zilkiciem, podzielona na trzy mešihaty: serbski, sandżacki i preszewski ${ }^{31}$. Aktualnie obie wspólnoty istnieją równolegle jako muzułmańskie wspólnoty wyznaniowe na obszarze Republiki Serbii.

${ }^{29}$ Tamíe.

30 Obnovljeno Narodno Vijeće Sandžaka, „Bošnjaci.net. Web magazin”, 12 IX 2011, http://www.bosnjaci.net/prilog.php?pid=43380; S. Novosel, Mogući...

${ }^{31}$ K. Kujawa, Konflikt muzutmańsko-muzutmański w Serbii, „Stosunki Międzynarodowe", 17 IX 2010, http://www.stosunki.pl/?q=content/konflikt-muzu\%C5\%82ma\% C5\%84sko-muzu\%C5\%82ma\%C5\%84ski-w-serbii (dostęp 18 IV 2012). 
Wspólnota Islamska Serbii nie jest instytucją tak kontrowersyjną jak Wspólnota Islamska w Serbii (ze względu na swojego muftiego), ale jest na pewno instytucja konkurencyjną i jej przedstawiciele starają się przedstawiać ją jako „prawdziwą" reprezentację wyznaniową wszystkich muzułmanów państwa serbskiego. Przyczyną była kwestia powiązań politycznych. Wspólnota M. Zukorlicia jako ta, która podlegała zwierzchnikom w Bośni i Hercegowinie, mogłaby jednoczyć wokół siebie nie tylko przedstawicieli narodu boszniackiego, niezadowolonych z polityki serbskiego rządu, ale i innych wyznawców islamu, np. Albańczyków czy Turków. Przedstawiciele Wspólnoty Islamskiej Serbii tłumaczyli, że posiadanie siedziby w Belgradzie rozwiązywało wiele kwestii organizacyjnych, instytucjonalnych oraz mogłoby ułatwić kontakt z władzami państwowymi. Z drugiej jednak strony instytucja ta była i jest narażona na zarzuty ulegania wpływom i kontroli władz serbskich. Należy również wspomnieć, że instytucja podkreślała swój wielonarodowy charakter, gdyż Boszniacy stanowili 30\% ogółu jej członków, Albańczycy 18\%, pozostałe zaś 52\% to „Romowie, Aškalijczycy, Gorańcy (lub Goranie), Egipcjanie, Turcy i inni”" ${ }^{2}$.

Wspólnota reis-ul-ulema A. Zilkicia odwoływała się do ciagłości historycznej tej instytucji, chcąc dodać jej prestiżu i z pewnością wiarygodności wobec silnego konkurenta, w dodatku prezentujaccego chwytliwe i radykalne hasła oraz nieprzejednane stanowisko zarówno religijne, jak i polityczne. Jeśli chodzi o ciagłość historyczna, to powoływała się na postanowienia Rady Państwa Księstwa Serbii z 13 maja 1868 r., kiedy to moca prawa uznano islam za religię istniejącą w ramach Księstwa. Następnie fakt ten potwierdzono w Ustawie o Kościołach i związkach wyznaniowych z 1930 r. W okresie komunistycznym istniała Wspólnota Islamska Jugosławii, która - we własnej opinii - została nielegalnie rozwiązana w $1993 \mathrm{r}$. w Istambule na mocy aktu podpisanego przez czworo sygnatariuszy z obszaru byłej Jugosławii. W wyniku rozpadu państwa powstały inne - według Wspólnoty Islamskiej Serbii „nielegalne” - wspólnoty islamskie (m.in. Wspólnota Islamska w Serbii), które wprowadziły wiele gruntownych przemian w dotychczasowych strukturach. Oficjalne źródła nie podały jednak, że jeszcze w okresie komunistycznym, na poziomie republik, istniały muzułmańskie przedstawicielstwa Wspólnoty Islamskiej w Jugosławii, które w wyniku rozpadu miały okazję uzyskać status państwowych. Wspólnota Islamska Serbii odcięła się jednak od tego wątku, podając w swoich oficjalnych źródłach, że w miejsce nielegalnie rozwiązanej Wspólnoty Islamskiej w Jugosławii powstała już w roku następnym, na Zgromadzeniu Wspólnoty Islamskiej w Nišu, Wspólnota Islamska Serbii. Miała być ona pełnoprawną kontynuatorką tej, która wchodziła w skład Wspólnoty Islamskiej w Jugosławii z siedzibą w Sarajewie.

${ }^{32}$ Karakter i načela, [w:] Islamska Zajednica Srbije, Mešihat Islamske Zajednice Sandžaka. Rijaset Islamske Zajednice Srbije, http://www.mesihatsandzaka.rs/islamska zajednicasrbije/ (dostęp 17 IV 2012). 
Interesujacy może być fakt, że przedstawicielstwo Wspólnoty Islamskiej w Jugosławii na terenie ówczesnej socjalistycznej Republiki Serbii miało swoją siedzibę w Prisztinie (Kosowo), co z racji konfliktu serbsko-albańskiego mogło utrudniać działalność instytucji, stąd prawdopodobnie postanowienia z roku 1994 i przeniesienie siedziby do Belgradu. W 2007 r. postanowieniem Zgromadzenia zostaje ustanowiony Rijaset Islamskiej Wspólnoty Serbii (niezależne, najwyższe władze instytucji), co przez Wspólnotę Islamską w Serbii, podlegającą rijasetowi w Bośni i Hercegowinie, zostało odebrane jako ,jednostronny i bezprawny akt”" ${ }^{\prime 3}$.

Jeśli chodzi o te dwa przywództwa religijne, Wspólnota Islamska w Serbii, na czele której od wielu lat stoi mufti M. Zukorlić, być może nie byłaby instytucją tak kontrowersyjna, gdyby nie sylwetka i wszechstronna działalność jej przywódcy. W ostatnich latach mówiło się o nim więcej jako o biznesmenie i polityku, niż jako przywódcy religijnym. Stojąc na czele ugrupowania BKZ jest chyba największym krytykiem władz serbskich, podkreślającym dyskryminacyjną politykę serbskiego rządu wobec regionu i społeczności sandżackiej, która miała trwać niezmiennie od 20 lat. Bezkompromisowe i radykalne hasła nie znalazły i nie znajduja jednak posłuchu wśród całej społeczności Sandżaku. Aida Ćorović z Urban-In była jedną z osób ostro krytykujących muftiego, a nawet weszła z nim w bezpośredni konflikt. Zarzuciła mu usilne generowanie problemów, które miały nie dopuścić do stabilizacji regionu oraz porozumienia serbsko-boszniackiego. Według jej opinii przywódca Wspólnoty Islamskiej realizował ten sam scenariusz, według którego działał S. Ugljanin w latach 90., prezentując się wówczas jako największy wróg reżimu S. Miloševicia, który chciał odłączyć Sandżak. Miało się później okazać, że działał w porozumieniu z państwowymi służbami bezpieczeństwa. Podobnie miał postępować M. Zukorlić, który świadomie i za pomoca sprawdzonych metod stosowanych przez służby bezpieczeństwa stwarzał atmosferę schizofrenii wśród obywateli Sandżaku. Jedną mniejszość narodową usilnie mobilizował przeciwko państwu, korzystając - według A. Ćorović - z półprawdy, czasem prawdy, jednak dyskusyjne było, komu to przynosiło korzyści. Jako dowód czystej manipulacji i wykorzystywania spraw mniejszościowych dla własnych korzyści podawała fakt, że mufti stał na czele Wspólnoty Islamskiej w Serbii od wielu lat, przyjaźnił się m.in. z inicjatorem demokratycznych przemian w tym państwie, zamordowanym w 2003 r. premierem Zoranem Đinđiciem, i nigdy nie poruszał tematu złego położenia mniejszości sandżackiej, przynajmniej w aspekcie religijnym. $\mathrm{W}$ ostatnich latach, rzekomo w imię islamu, co miało być tylko zasłoną dla jego prawdziwych pobudek - podjał działania, które są efektem obliczonym na zdobycie szerszego poparcia w kampanii wyborczej ${ }^{34}$.

${ }^{33}$ S. Barišić, Muslimani i raspad SFRJ, „Peščanik”, 4 IX 2008, http://pescanik. net/2008/09/muslimani-i-raspad-sfrj/; zob. też K. Kujawa, dz. cyt.

${ }^{34}$ S. Novosel, Muftija... 
Powyższa krytyka przeniosła się również na inne aspekty życia społecznego. Dyrektorka Urban-In wywołała publiczną debatę, narażając się radykalnym muzułmanom, kiedy zabrała głos w sprawie noszenia hidżabów przez muzułmańskie kobiety. Ćorović promowała feminizm wśród muzułmanek, opowiadając się za ich prawem i swoboda wyboru, np. co do noszenia chust czy też innych okryć, jeśli tylko w ten sposób miały zamanifestować swoją religijność. Zarzuciła muftiemu, że kreował „obraz posłusznej muzułmańskiej kobiety, dostosowanej do obyczajów Zukorlicia". Miało to zapewnić mu kontrolę - poza tymi, na których już miał wpływ - na muzułmańskie rodziny, ,jak to miało miejsce w Afganistanie i gdzie indziej" ${ }^{35}$. Równocześnie jednak była przekonana, że poprzez promowanie swojego anachronicznego podejścia do układu w społeczeństwie, mufti stopniowo tracił poparcie.

Jeśli chodzi o stosunek do władz serbskich, to M. Zukorlić zarzucał tzw. reżimowi belgradzkiemu, że nie traktował Boszniaków jako równoprawnych obywateli, co głównie miało być zauważalne w mediach, w których dopuszczano do nagonki na boszniackie instytucje wyznaniowe, uwzględniając również „wyborczą farsę" do Boszniackiej Rady Narodowej, na czele której Belgrad chciałby postawić „swoich ludzi”, nie dopuszczając tym samym, aby problemy regionu zostały rozwiązane ${ }^{36}$. W wywiadzie dla Sandžak Press (wiadomości internetowych regionu) Zukorlić stwierdził, że oskarżenia o wywoływanie nieporozumień i konfliktów z serbskimi władzami lub też innymi organizacjami stawiano mu dlatego, że nie popierał „reżimu”. Jako potwierdzenie swoich racji wskazał bardzo dobre relacje z inicjatywami obywatelskimi i organizacjami pozarządowymi. Swój konflikt z A. Ćorović usprawiedliwił z kolei obroną kobiet muzułmańskich, które miały być obiektem ataków dyrektorki Urban-In. Zarzucił jej również, że taką obronę nazywała „językiem nienawiści”, podczas gdy sama „przeliczała ile mamy dzieci, żon, zaglądała do naszego życia prywatnego i tlumaczyła to wszystko wolnością słowa" ${ }^{37}$.

Na zarzut zbyt silnego zaangażowania w politykę A. Zukorlić odpowiedział, że jest to jego reakcja na wcześniejsze ataki ze strony polityków. Wytłumaczył, że broniąc się przed nimi nie mógł sam nie zaangażować się w politykę. Ponadto podkreślił, że nie zabraniała mu tego ani konstytucja, ani prawo ${ }^{38}$.

${ }_{35}$ Tamíe.

${ }^{36}$ Chodziło o brak akceptacji wybranej Rady, na czele której staną M. Zukorlić i jego zwolennicy, którzy zdobyli najwięcej głosów. Władze w Belgradzie wprawdzie wskazywały na konieczność nowych wyborów do BNV, jednak data tych wyborów była kilkakrotnie przekładana i w rzeczywistości nie odbyły się one do dnia dzisiejszego.

${ }^{37}$ Kritikujem režim a ne državu i Srbe, „Sandžak Press. Elektronske novine”, 4 III 2011, http://sandzakpress.net/kritikujem-rezim-a-ne-drzavu-i-srbe (dostęp 20 II 2012).

38 Tamíe. 
M. Zukorlić nie był jednak jedynym działaczem krytykujacym władze serbskie. Na początku grudnia 2010 r. Sandżacka Partia Narodowa (Sandžačka narodna partija, SNP) z Mirsadem Đerlekiem na czele złożyła petycję do władz serbskich, aby zredefiniowano status narodowy Boszniaków w Serbii, uznając ich za naród konstytutywny. Kolejne zmiany miały dotyczyć zreformowania administracji w myśl koncepcji regionalizacji, co miałoby doprowadzić do decentralizacji, w której Sandżak byłby jednolitym regionem, Nowy Pazar zaś centrum kulturalnym, ekonomicznym i politycznym. Swoje żądania ugrupowanie uzasadniało fatalnym położeniem socjalno-ekonomicznym społeczności zamieszkującej ten obszar, zarzucając władzom centralnym, że nie miały pomysłu, jak rozwiązać te oraz inne problemy, które wiązały się z funkcjonowaniem Boszniackiej Rady Narodowej czy też Wspólnoty Islamskiej ${ }^{39}$.

Z kolei przewodniczący NVS Dž. Suljević przedstawił jeszcze bardziej radykalny projekt przemian dotyczących Sandżaku, otwarcie popierając niepodległość tego regionu, jednak podkreślał, że według programu NVS odłączenie jego terytorium od Serbii dla samego odłączenia nie wchodzi w grę. Autonomia była pierwszym krokiem w procesie przyłączenia do Bośni i Hercegowiny. Należy dodać, że plany obejmowały również czarnogórską część obszaru, Suljević odwoływał się zaś do tzw. partyzanckiej autonomii, którą sandżacki obszar miał w okresie 19431945, kiedy to stanowił „równoprawna jednostkę federalna” wraz z pozostałymi republikami byłej Jugosławii. Dla porównania polityk podał przypadek Republiki Serbskiej (części składowej Bośni i Hercegowiny), której kontrowersyjny prezydent Milorad Dodik otwarcie popierał odłączenie od $\mathrm{BiH}$ i przyłączenie go do Republiki Serbii. Według przewodniczącego NVS ten region nie istniał w historii jako odrębna jednostka terytorialna w przeciwieństwie do Sandżaku, który miał swoje określone granice. Aktualnie był on podzielony między dwa państwa, a na jego terytorium trwała „ekonomiczna dyskryminacja i asymilacja kulturowa”, w myśl której boszniackie dzieci uczyły się „cudzej”, bo serbskiej, historii i kultury. Podkreślił również, że Boszniacy byli jedynymi autochtonami, którzy nie mieli swojego własnego państwa na terytorium byłej Jugosławii, a sama NVS miała być instytucją wszystkich mieszkańców tego obszaru, nie zaś samych Boszniaków ${ }^{40}$.

39 Uwzględniając kwestię zmiany statusu narodu boszniackiego, należałoby się bliżej przyjrzeć argumentacji jego przedstawicieli. Boszniacy sa - po Węgrach - drugą najliczniejszą mniejszością narodową w Serbii, ich odsetek wynosi 1,82\% ogółu mieszkańców tego kraju. Dodając do tego również mniejszość zadeklarowaną jako Muzułmanie, których jest $0,26 \%$, otrzymalibyśmy niewiele ponad $2 \%$, co daje prawie dwukrotnie mniejszą liczbę, w porównaniu z Węgrami - 3,91\%. N. Gojković, dz. cyt., s. 2; Nacionalne manjine, Web-site Vlade Republike Srbije, http://www.arhiva.srbija.gov.rs/cms/view.php?id=1019 (dostęp 26 XII 2011); Da Bošnjaci budu konstitutivni narod, „Danas”, 6 XII 2010, http://www.danas.rs/dodaci/sandzak/da_bosnjaci_budu_konstitutitvni_narod_.42.html?news_id=205965 (dostęp 4 I 2012).

${ }^{40}$ G. Bašić, dz. cyt., s. 79; Džemail Suljević sanja "Sandžak Republiku”, „Kurir”, 16 VIII 2010, http://www.kurir-info.rs/dzemail-suljevic-sanja-sandzak-republiku-cla- 
Postawa Dž. Suljevicia spotkała się z powszechną krytyką zarówno ze strony serbskiej, jak i boszniackiej. Sekretarz Sandżackiej Partii Demokratycznej (Sandžačka demokratska partija, SDP) Mirsad Jusufović stwierdził, że idea autonomii jest przestarzała i nie powinno się do niej wracać, a zwłaszcza nie powinni tego robić politycy, którzy nie maja poparcia obywateli. Podkreślił, że Boszniacy nie potrzebowali autonomii, tylko rozwoju przedsiębiorstw i stabilizacji ekonomicznej. Z kolei działacze SDA nie chcieli w ogóle komentować wywodów Suljevicia ${ }^{41}$.

Ten choćby przykład świadczy o braku jednolitego stanowiska wśród tej mniejszości. Należy jednak zauważyć, że wszyscy działacze, zaangażowani społecznie, religijnie lub politycznie, zgodni byli co do jednego: region znajdował i znajduje się w bardzo złym położeniu ekonomicznym. Wspólne podjęcie działań w celu wydźwignięcia go z kryzysu przyniosłoby z pewnością efekty, jednak przywódcy ugrupowań i instytucji wolą koncentrować się na walce między sobą. Z kolei każda inicjatywa Belgradu, czy to samodzielna, czy też we współpracy z boszniackimi reprezentantami, jest postrzegana jako zamach na prawa mniejszościowe.

Nie należy jednak marginalizować poglądów, które reprezentuje Suljević. Być może polityk ten z pewnych względów nie zgromadził wokół siebie odpowiedniej liczby zwolenników, jednak to nie oznacza, że idea niepodległego Sandżaku, czy też raczej wchodzącego w skład Bośni i Hercegowiny, nie ma zwolenników. Jako przykład można podać istniejący na popularnym portalu społecznościowym Facebook Ruch dla Niepodległego Sandżaku, który liczy sobie około 4 tys. członków. Ich przewodnią idea jest nie tylko dążenie do utworzenia niepodległego Sandżaku, ale również przyłączenie go do Bośni i Hercegowiny. Na stronie umieszczono napis: „Witamy w Republice Sandżaku”. Znajdowało się tam również zdjęcie Nasera Oricia oraz mapa, na której region jest częścią $\mathrm{BiH}^{42}$.

W połowie czerwca 2011 r. duże poruszenie wywołały słowa ministra spraw zagranicznych Serbii Vuka Jeremicia, który w wywiadzie udzielonym dla stacji radiowej B92 stwierdził, że „wszyscy wiedza, że istnieją obszary Serbii, gdzie występują etniczne napięcia, gdzie sa ludzie, którzy nadużywają religijnego rozsądku i zobowiązań obywatelskich” ${ }^{{ }^{43}}$. Następnie w debacie z liderem Partii

nak-44956 (dostęp 4 III 2012); Sandžak traži „partizansku autonomiju”, „Vesti online”, 9 VIII 2010, http://www.vesti-online.com/Vesti/Srbija/73585/Sandzak-trazi-partizansku-autonomiju (dostęp 4 III 2012).

${ }^{41}$ G. Bašić, dz. cyt., s. 43; Džemail Suljević sanja...

${ }^{42}$ Naser Orić w czasie wojny w BiH był dowódcą Armii Republiki Bośni i Hercegowiny na obszarze Srebrenicy. Sądzony w Hadze za zbrodnie popełniane przeciwko serbskiej ludności na tym terytorium otrzymał wyrok dwóch lat więzienia, co spotkało się z falą krytyki za zbyt niski wymiar kary za popełnione czyny. Džemail Suljević sanja...

${ }^{43}$ S. Čongradin, S. Novosel, Traže smenu Jeremića zbog izjava o Sandžaku, „Danas", 22 VI 2011, http://www.danas.rs/danasrs/politika/traze_smenu_jeremica_zbog_izjava_o_sandzaku.56.html?news_id=217969 (dostęp 12 XII 2011). 
Liberalno-Demokratycznej (Liberalno-demokratska partija, LDP) Čedomirem Jovanoviciem potwierdził, że miał na myśli Sandżak. To właśnie przedstawiciele sandżackich siedzib LDP najostrzej zareagowali na te słowa. Kenan Hajdarević oskarżył ministra o satanizację Sandżaku i Boszniaków, których przedstawił jako secesjonistów, region zaś jako następne Kosowo. Zaznaczył, że władze serbskie bezsprzecznie powinny zmienić politykę wobec regionu, pamiętając o tym, że również jego mieszkańcy postrzegali Serbię jako swoje państwo, szanowali jej prawo, ale nie chcieli być „dyżurnymi winnymi”, odpowiadajacymi za wszystkie pojawiające się problemy. Ostatecznie zażądał od premiera Mirko Cvetkovicia zmiany na stanowisku szefa dyplomacji ${ }^{44}$.

Jako alternatywę dla stanowiska „niezadowolonych Boszniaków” spod znaku M. Zukorlicia, A. Ćorović przedstawiała młodzież muzułmańska, chętną do działania i współpracy, która miała zapał i chęć wprowadzania zmian w społeczeństwie. Jednym z przykładów możliwości zaktywizowania społeczności tego regionu i podjęcia współpracy z Serbami było choćby założenie Koordynacji Społeczeństwa Cywilnego w Sandżaku przez kilka pozarządowych organizacji z tego regionu we współpracy z belgradzkim Centrum dla Praktycznej Polityki. Celem miało być stworzenie dokumentu, w którym opisano by podstawy rozwiązania problemów tego obszaru. Ćorović wyraźnie zaznaczyła - podobnie jak Hajdarević - że Serbia była również państwem Boszniaków z Sandżaku i zasługiwali oni na to, aby ten obszar był najlepszą częścią kraju. Z drugiej strony, państwo powinno pomóc w znalezieniu choćby partnerów strategicznych z zagranicy, aby móc gospodarczo rozwinać region i znaleźć ludziom zatrudnienie. Potwierdziła istotny i dość oczywisty fakt, że jeśli mieszkańcom żyłoby się dobrze, to „żadna autorytarna idea nie znalazłaby tutaj poparcia" ${ }^{\prime 4}$.

Rozbieżność postaw wobec określenia stanowiska Boszniaków w serbskiej rzeczywistości pojawiła się również w momencie przeprowadzenia spisu ludnościowego, który rozpoczął się w Sandżaku w kwietniu 2011 r. BNV, zdominowana przez M. Zukorlicia i jego zwolenników, wezwała Boszniaków do bojkotu tego spisu. Jako przyczynę podano tekst formularza spisowego, sporządzonego cyrylicą i w języku serbskim, co łamało zagwarantowane w konstytucji prawa mniejszości do stosowania własnego języka. Apel ten został ponowiony we wrześniu tego samego roku przez przewodniczącego NVS Dž. Suljevicia oraz innych działaczy Rady, którzy również wezwali do bojkotu wszystkich mieszkańców regionu. Jako powód podali dyskryminacyjną politykę Belgradu, której przejawem miał być nie tylko sporny formularz spisu, ale i fałszowanie statystyk, mających na celu zaniżenie faktycznej liczby przedstawicieli boszniackiego pochodzenia. Akcja ta miała być pierwszym krokiem obywatelskiego nieposłuszeństwa, które wymienione było w Deklaracji o Dyskryminacji w Sandżaku

\footnotetext{
${ }^{44}$ Tamíe.

${ }^{45}$ S. Novosel, Muftija...
} 
jako forma oporu wobec władz serbskich. Pojawiły się również pogłoski na temat gróźb i zastraszania osób publicznych nawołujacych do bojkotu. Jak stwierdził przewodniczacy Komitetu Wykonawczego NVS Sead Šacirović, wielu Boszniaków nie przyznawało się do swego pochodzenia ze względu na obawy przed dyskryminacja. Według niego najwięcej przedstawicieli tej narodowości było wśród osób deklarujących się jako Muzułmanie i Jugosłowianie, problem z dokładnym określeniem przynależności narodowej polegał zaś na tym, że w spisie każdy miał możliwość dowolnego wpisywania własnej narodowości, a nie wybierania z listy, przez co wciąż uwzględniane były muzułmańskie i jugosłowiańskie kategorie narodowe. Podkreślał również, że jedyną możliwością rozwiązania problemu sandżackiego był „upadek reżimu” i postawienie na czele miast regionu „szanowanych Boszniaków”46.

Stanowiska Boszniaków wobec tej akcji były jednak podzielone, większość z nich zignorowała ten apel. Wielu prominentów uważało bojkot za błąd działający na szkodę samej mniejszości. Konieczność spisania się w celu określenia jednoznacznej liczby przedstawicieli mniejszości bośniackiej była niezbędna z punktu widzenia ich interesów. Tego zdania byli choćby przedstawiciele dwóch partii: Rešad Hodžić z SDP i Fevzija Murić z Partii dla Sandżaku (Stranka za Sandžak, SZS ${ }^{47}$. Obrazowało to trwająca w zasadzie do dziś sytuację społeczeństwa sandżackiego, którą odzwierciedlała również płaszczyzna polityczna. Część społeczności opowiadała się za współpracą z Belgradem i działalnością w ramach przyznanych mniejszościom praw. Ich przeciwnicy uważali, że prawa te były łamane w Serbii, obecne władze mówiły zaś językiem starego reżimu z lat 90. XX w. W związku z tym jakakolwiek współpraca była bezcelowa, a problem powinien zostać umiędzynarodowiony.

$\mathrm{Na}$ tle tych przeciwstawnych stanowisk interesująca rolę odgrywali Boszniacy wchodzący w skład ówczesnego rządu lub zasiadający w Skupsztinie. Można tutaj wymienić S. Ugljanina, przywódcę SDA - symbol walki boszniackiej o autonomię w latach 90 . XX w. - ministra bez teki, R. Ljajicia - ministra pracy i polityki socjalnej, a także przewodniczącego z SDP, oraz E. Džudževicia - parlamentarzysty, a równocześnie przewodniczącego Komitetu Wykonawczego (mandat techniczny) poprzedniej BNV.

Obaj ministrowie byli i sa ze sobą skonfliktowani, co budziło zarzuty ze strony samych Boszniaków. Na początku lipca 2011 r. publicysta Fahrudin Kladničanin twierdząc, że za sytuację w Sandżaku odpowiedzialność ponoszą sami Boszniacy, wskazał na kilka głównych problemów, które przyczyniały się

${ }^{46}$ Predsjednik Sandžaka Džemail Suljević pozvao na bojkot srpskog popisa, „Bošnjaci.net”, 30 IX 2011, http://www.bosnjaci.net/prilog.php?pid=43581 (dostęp 20 III 2012).

${ }^{47}$ K. Živanović, S. Novosel, SDP pogrešno knjižio sredstva, „Danas”, 5 XII 2011, http://www.danas.rs/danasrs/drustvo/sdp_pogresno_knjizio_sredstva.55.html?news_ id=229569 (dostęp 4 XII 2011). 
do braku poprawy sytuacji w regionie, z czego najważniejszym było - jego zdaniem - koncentrowanie się na wewnętrznych konfliktach politycznych, zamiast korzystania z nowej sytuacji politycznej. Kladničanin przyznał, że nigdy jeszcze w państwowych instytucjach nie było tak silnej reprezentacji boszniackiej, jak w tym momencie i nie było to wykorzystywane w dostatecznym stopniu do polepszenia wizerunku regionu, podniesienia stopy życiowej jego mieszkańców, zwiększenia ich zatrudnienia oraz inwestycji, które były obiecywane już od dość długiego czasu ${ }^{48}$.

R. Ljajić potwierdził brak porozumienia między boszniackimi politykami stwierdzając, że o ile naturalna była jego współpraca z S. Ugljaninem na niwie rządowej, to na płaszczyźnie lokalnej nie chciał z nim kooperować. Podkreślił jednak, że dla dobra mieszkańców Sandżaku i poprawy sytuacji w tym najbiedniejszym regionie, jego ugrupowanie mogło współdziałać z SDA, ale nie było mowy o wspólnym publicznym pojawianiu się. Skrytykował również politykę rządu, który przyjął postanowienia o sfinansowaniu subwencji związanych z zatrudnianiem ludzi w Nowym Pazarze i czterech innych miastach, co nie przełożyło się na żadne konkretne działania. Podobnie wyglądała sytuacja z tureckimi inwestorami, którzy interesowali się regionem, jednak wstępne projekty i obietnice inwestycyjne nie dochodziły do skutku, co Ljajić składał na karb wizerunku obszaru burzliwego i niestabilnego politycznie ${ }^{49}$.

Jeśli chodzi o S. Ugljanina, to wystosował on list do prezydenta, premiera i przewodniczącej serbskiej Skupsztiny, w którym domagał się zdjęcia ze stanowisk szefów wszystkich posterunków w sandżackich okręgach, wymianę wszystkich kadr zatrudnionych w policji, sądownictwie, prokuraturze i instytucjach, które przyczyniły się do łamania praw Boszniaków. Przyczyną tak radykalnej postawy był incydent związany z życiem prywatnym ministra, więc motywy jego postępowania mogły być dyskusyjne. Mianowicie, to ostre wystapienie nastapiło po wydarzeniu, w którym jego małoletni syn został zatrzymany przez policję $\mathrm{w}$ wyniku popełnionych czynó $\mathrm{w}^{50}$.

E. Džudžević, zasiadający w serbskim parlamencie, również otwarcie krytykował władze, zarzucając Serbom, że nie odpowiadałaby im okoliczność, w której Boszniacy wystapiliby jako jednolita, zwarta grupa społeczna, reprezentowana przez zgodny front polityczny. Trójpodział jaki panował (i panuje nadal) na terytorium Sandżaku był - według niego - na rękę Serbii, ponieważ osłabiał żywioł boszniacki, pozwalając w istocie prowadzić Serbom swoją własną politykę

${ }^{48}$ F. Kladničanin, Šta treba Sandžaku?, „Danas”, 5 VII 2011, http://www.danas.rs/ danasrs/dijalog/sta_treba_sandzaku.46.html?news_id=218860 (dostęp 13 XII 2011).

${ }^{49}$ Ljajić: Saradnja sa Ugljaninom u interesu naroda, „Bošnjaci.net”, 10 II 2011, http://bosnjaci.net/prilog.php?pid=40616 (dostęp 10 IV 2011).

50 S. Novosel, Odmrzavanje madata u zamenu za prečišćavanje policije, „Danas”, 24 XI 2011, http://www.danas.rs/dodaci/sandzak/odmrzavanje_madata_u_zamenu_za_ preciscavanje_policije.42.html?news_id=228836 (dostęp 2 XII 2011). 
na tym obszarze. Jeśli chodzi o ów trójpodział, to Džudžević podał trzy nurty w polityce, które obrazowały również podziały wśród Boszniaków: liberalny, radykalny oraz wypośrodkowany, tworzący „trzecią drogę”. Pierwszy nurt, „obywatelsko-liberalny”, był reprezentowany przez R. Ljajicia, drugi, „radykalno-wyznaniowy", uosabiał M. Zukorlić. Drogę pośrednią miał reprezentować właśnie E. Džudžević, który uważał, że kluczowymi rozwiąaniami dla mniejszości była decentralizacja i regionalizacja, która doprowadziłaby do utworzenia upragnionej autonomii, co z kolei przyczyniłoby się do poprawy warunków ekonomicznych oraz możliwości prowadzenia prawdziwej walki politycznej według przysługującego prawa mniejszościowego. Stwierdził też, że właśnie realizacja tych trzech zależności nie odpowiadała państwu serbskiemu, natomiast sami Boszniacy to uniemożliwiali. Jako przykład podał „fenomen Zukorlicia”, który - utrzymując stan napięcia politycznego - przyczyniał się swoim działaniem do postrzegania Sandżaku jako regionu niestabilnego. To z kolei dało pretekst, aby nie rozpoczynać, a nawet zarzucić ekonomiczne projekty, jakie powstały w wyniku porozumienia Serbii i Turcji. Zgodził się jednak z opinią krytykowanego muftiego, że aktualny podział administracyjny, dzielący Sandżak pomiędzy dwa państwa, bardzo utrudniał życie codzienne jego mieszkańców ${ }^{51}$.

Džudžević wskazał również na zjawiska dyskryminujące reprezentowaną przez niego mniejszość. Chodziło o brak realizacji obietnic związanych z zatrudnieniem w wojsku i policji, lepszy dostęp do mediów, niestosowanie języka urzędowego w miejscowościach, w których powinno to być robione (Nowy Pazar, Tutin, Sjenica, Prijepolje). Sprawę skierowano do rzecznika praw obywatelskich, oskarżone zaś zostały: Ministerstwo Praw Człowieka i Mniejszości, Ministerstwo Spraw Wewnętrznych, Oświaty i Kultury. Możliwa była również opcja zaskarżenia do Trybunału Konstytucyjnego. Jeśli chodziło o impas związany z wyborami do BNV, oskarżał o przyczynienie się do niego ministra Svetozara Čiplicia oraz M. Zukorlicia. Zarówno przedstawiciele władz serbskich, jak i zagraniczni dyplomaci oraz szef misji OBWE w Serbii uczestniczyli w rozmowach, które mogłyby przełamać kryzys związany z Rada, jednak rozmowy te nie doprowadziły do konsensusu. Džudžević określił siebie i swoją Boszniacką Listę jako „konstruktywnego partnera”, któremu w zasadzie odpowiadałby każdy wyznaczony przez Belgrad termin wyborów do BNV, nawet jeśli byłby to termin pokrywający się z wyborami lokalno-parlamentarnymi (maj 2012 r. $)^{52}$. Tym samym mogłoby się wydawać, że zajął stanowisko prorządowe, nieuznające wyboru BNV w lipcu $2010 \mathrm{r}$.

${ }^{51}$ S. Novosel, Državi ne odgovara da se Bošnjaci dogovore, „Danas”, 19 V 2011, http://www.danas.rs/dodaci/sandzak/drzavi_ne_odgovara_da_se_bosnjaci_dogovore.42.html?news_id=215569 (dostęp 30 III 2012).

${ }^{52}$ Tamize. 
W lipcu 2011 r. E. Džudžević „zamroził” swój mandat w parlamencie, co miało być aktem protestu wobec incydentu, w trakcie którego w jego samochodzie przebito opony, co uznał za akt dyskryminacji inspirowany przez członków rządu. Ta ostra reakcja wywołała krytykę ze strony Boszniackiej Wspólnoty Demokratycznej (Bošnjačka demokratska zajednica, BDZ) Emira Elficia, który zarzucił mu, że przez taką postawę nie wywiązywał się z misji, którą powierzyli mu wyborcy, oddając na niego swój głos. Co więcej, kolejny postawiony zarzut dotyczył celowego zdystansowania się do pełnionej funkcji w celu rozpoczęcia kampanii wyborczej szeregu ugrupowań, którym przewodzić miał S. Ugljanin ${ }^{53}$.

Džudžević otwarcie krytykował również Zukorlicia zarzucając mu, że dążył do „klerykalizacji” Boszniaków, czemu przeciwstawiał się nie tylko sam Džudžević i jego zwolennicy, ale i większa część społeczności boszniackiej z obszaru Serbii, co miało świadczyć o „europejskim charakterze narodu”. Przewodniczący Komitetu Wykonawczego BNV postawił dodatkowy zarzut, że poprzez takie działania przywódca Wspólnoty Islamskiej w Serbii miał na celu kontrolę życia społecznego w Sandżaku w aspekcie religijnym, politycznym i kulturowym. Był to kolejny, po wystapieniu A. Ćorović, głos, stawiajacy takie same zarzuty. Jako ciekawostkę, można podać fakt, że swoje poparcie dla Zukorlicia wycofał Bakir Izetbegovic ${ }^{54}$.

Warto wspomnieć jeszcze o tym, że E. Džudžević stał na czele Centrum Studiów Boszniackich, które znajdowało się w Tutinie i było jedynym wydawnictwem, które publikowało książki w języku bośniackim. Na początku $2011 \mathrm{r}$. do szkolnych i miejskich bibliotek wszystkich sześciu okręgów sandżackich trafiły podręczniki z zakresu historii, literatury, kultury i języka bośniackiego dla klas od I do VIII, co zostało przeprowadzone przez tę instytucję. Co więcej, od roku szkolnego 2012/2013 będzie obowiązywał nowy program kształcenia dla

53 Vreme je da država ispuni obećanja, „Danas”, 7 VII 2011, http://www.danas. rs/dodaci/sandzak/vreme_je_da_drzava_ispuni_obecanja.42.html?news_id=219013 (dostęp 14 XII 2012); S. Novosel, Predizborna trka ili kršenje prava Bošnjaka, „Danas”, 17 VII 2011, http://www.danas.rs/danasrs/politika/predizborna_trka_ili_krsenje_prava_ bosnjaka.56.html?news_id=219682 (dostęp 14 XII 2011).

${ }^{54}$ Bakir Izetbegović (syn pierwszego prezydenta Bośni i Hercegowiny Aliji Izetbegovicia) swój polityczny rodowód wywodzi z SDA. Sam siebie kreuje na polityka umiarkowanego, który dąży do dialogu z Serbami i Chorwatami w celu budowy stabilnego i rozwijającego się państwa. Z drugiej strony oskarżony jest przez przedstawicieli Grupy Eksperckiej Europy Południowo-Wschodniej dla Zwalczania Terroryzmu i Przestępczości Zorganizowanej o wspieranie i pomoc dla wahabitów, których w BiH ma być - według tej organizacji - około 100 tys. S. Novosel, Državi...; Галијашевић, Изетбеговић и Силајцић уз подршку Церића штите вехбије, РТРС, 30 I 2011, http://www.rtrs.tv/vijesti/vijest. php?id=34839; „Медийски обрачун” Изетбеговића и Радончића, РТРC, 16 XII 2011, http://rtrs.tv/vijesti/vijest.php?id=51870 (dostęp 30 III 2012). 
boszniackich dzieci, w którym będą się one uczyć języka bośniackiego, literatury oraz z zakresu kultury: malarstwa i muzyki. Program ten obją nauczanie na poziomie szkół podstawowych i średnich oraz w przedszkolach ${ }^{55}$.

Zwolennicy osób spod znaku M. Zukorlicia czy też Dž. Suljevicia nazywali zasiadających w serbskim rządzie ministrów S. Ugljanina i R. Ljajicia zdrajcami i wykonawcami „wielkoserbskiego reżimu" ${ }^{\prime \prime}$. Ponadto Zukorlić zapytany o możliwość współpracy z tymi politykami odpowiedział, że wchodziłaby ona w grę pod warunkiem, że obaj nie wzięliby udziału w wyborach do BNV, które ma rozpisać Belgrad $^{57}$.

Konflikty instytucjonalne i personalne między reprezentantami Sandżaku miały jeden dwuaspektowy mianownik, jeśli chodzi o wskazywanie podstawowych problemów w relacjach serbsko-boszniackich. Pierwszym było łamanie konstytucyjnego prawa do stosowania języka bośniackiego, co podkreślało większość działaczy. Drugim był fakt, że Sandżak należał do najuboższych regionów Serbii, co również rzutowało na relacje społeczne na tym obszarze. Analizując zaangażowanie zagranicznych inwestycji można było dostrzec, że dotychczas większość pomocy ekonomicznej lub programów rozwojowych dotyczyła południa Serbii, zamieszkałego m.in. przez ludność albańską i bułgarska. Aktywiści sandżaccy, reprezentujący również organizacje pozarządowe, w ostatnich latach intensywnie pracowali nad promocją regionu i przedstawieniem go jako obszaru atrakcyjnego rozwojowo. Doprowadziło to do zainteresowania nim Turcji. W 2011 r. doszło do wizyty prezydenta Turcji Abdullaha Güla w Serbii, gdzie spotkał się z prezydentem Borisem Tadiciem. Jednym z tematów rozmów było właśnie zwiększenie inwestycji tureckich w Serbii, w tym w rejonie Sandżaku ${ }^{58}$.

Wizyta turecka w Belgradzie oraz potencjalne inwestycje wywołały również reakcję M. Zukorlicia. Deklarację zaangażowania Turcji w rozwój regionu określił on „krokiem naprzód, który mógł przyczynić się do złagodzenia napięcia w regionie". Jako ciekawostkę można podać fakt, że Zukorlić w związku ze swoją

${ }_{55}$ Podeljene knjige na bosanskom jeziku, „Sandzakvesti”, 11 II 2011, http://sandzakvesti.wordpress.com/2011/02/11/podeljene-knjige-na-bosanskom-jeziku/ (dostęp 1 IV 2012); Sandžak: Bosanski od sljedeće godine redovan predmet, „Bošnjaci.net. Web magazin”, 16 XI 2011, http://bosnjaci.net/prilog.php?pid=44210 (dostęp 20 IV 2012).

${ }^{56}$ F. Šantić, Sandžaklije na tudem zadatku, „Sandžak Press. Elektronske novine”, 4 III 2011, http://sandzakpress.net/sandzaklije-na-tudem-zadatku (dostęp 15 XI 2010).

${ }^{57}$ Kritikujem režim a ne državu $i$ Srbe, „Sandžak Press. Elektronske novine”, 4 III 2011, http://sandzakpress.net/kritikujem-rezim-a-ne-drzavu-i-srbe (dostęp 20 II 2012).

${ }^{58}$ Sandžak $i$ zaangażowanie ze strony Turcji, „Pokochaj byłą Jugosławię”, 27 IV 2011, http://pokochajbylajugoslawie.wordpress.com/2011/04/27/sandzak-i-zaangazowanie-ze-strony-turcji/ (dostęp 21 I 2012). 
kontrowersyjną działalnościa, nie został zaproszony do Turcji na spotkanie delegacji wspólnot muzułmańskich z regionu we wrześniu tego samego roku ${ }^{59}$.

Niewykluczone, że fakt ten związany był z projektem, który powstał w kolejnym miesiącu i zakładał utworzenie jednolitej muzułmańskiej instytucji religijnej, zrzeszającej wszystkich muzułmanów w Serbii, w miejsce obu istniejących. Pomysł ten opracowany został przez premiera Turcji Tayyipa Erdoğana, reis-ul-ulema Wspólnoty Islamskiej Turcji Mehmeta Gormeza, ówczesnego reis-ul-ulema Wspólnoty Islamskiej w Bośni i Hercegowinie Mustafę Cericia ${ }^{60}$, członka Prezydium BiH B. Izetbegovicia (kadencja 2010-2014), ministrów Ahmeta Davutoglu, S. Ugljanina i R. Ljajicia. Aby porozumienie mogło zacząć obowiązywać, powinni je podpisać przedstawiciele wszystkich trzech państw oraz aktualni zwierzchnicy wyznaniowych instytucji islamskich w Serbii, czyli A. Zilkić oraz M. Zukorlić. Ponadto ujęte w nim były pewne warunki, uniemożliwiające m.in. postawienie na czele nowej instytucji dotychczasowych przywódców religijnych, ich współpracownicy mieli zaś zakaz angażowania się w jakakolwiek działalność polityczna. Co więcej, wszystkie przejawy polityki miały być „wycofane” z instytucji wyznaniowych oraz meczetów. Porozumienie zawierało 15 punktów i według S. Ugljanina strona serbska zgodziła się je przyjąc ${ }^{61}$, co nie było prawdziwym stwierdzeniem, ponieważ władze Serbii odrzuciły projekt ze względu na kwestie administracyjne, według których na sześć nowo powstałych okręgów (muftijstv), na czele pięciu stałyby osoby z otoczenia M. Zukorlicia, a tylko jednego osoba ze Wspólnoty A. Zilkicia ${ }^{62}$.

Można się zastanowić, czy ów projekt miał na celu wzmocnienie Zukorlicia, czy też był manifestacją wycofania poparcia dla niego przez Wspólnotę Islamska w Bośni i Hercegowinie. Z jednej strony wydawać by się mogło, że rozszerzenie wpływów muftiego przez kontrolę nad większością jednostek administracyjnych wzmacniało jego pozycję jako jedynego przywódcy religijnej organizacji muzułmańskiej na terytorium jednego z największych państw na Bałkanach. Z dru-

${ }^{59}$ Sandżak reprezentowałRešad ef. Plojović, Turska protiv muftije Zukorlića, „Bošnjaci.net. Web magazin”, 7 X 2011, http://bosnjaci.net/prilog.php?pid=43675 (dostęp 21 I 2012); Sandžak i zaangażowanie...

${ }^{60}$ Funkcję tę piastował do września 2012 r., kiedy w wyborach jego miejsce zają Husejn Karazović. Aktualnie Cerić jest przywódcą założonego w 2012 r. Światowego Kongresu Boszniackiego oraz przewodniczącym Senatu BANU. Wraz z M. Zukorliciem (i innymi) był współzałożycielem tych instytucji.

${ }^{61}$ Ugljanin: Ponovi jedinstvena islamska zajednica, „Bošnjaci.net. Web magazin”, 14 X 2011, http://bosnjaci.net/prilog.php?pid=43771; Ljajić o Islamskoj Zajednici, Zukorliću, Ugljaninu, „Bošnjaci.net. Web magazin”, 23 X 2011, http://bosnjaci.net/prilog. php?pid=43898 (dostęp 20 IV 2012).

${ }^{62}$ Srbija odbila da potpiše dogovor o islamsko zajednici, „Bošnjaci.net. Web magazin”, 1 XI 2011, http://bosnjaci.net/prilog.php?pid=44040 (dostęp 20 IV 2012). 
giej zaś strony nie mógłby korzystać z protekcji władz islamskich w Sarajewie i bardzo dyskusyjna stałaby się jego działalność na rzecz politycznej autonomii Sandżaku, nie mówiąc już o przyłączeniu tego regionu do BiH. Poza tym, jeden z kluczowych warunków mógł zniechęcić go do tego projektu, a mianowicie całkowite odcięcie się od działań politycznych, co najprawdopodobniej Zukorlić mógł traktować jako silne ograniczenie jego pozycji, tym bardziej że postanowił on kandydować w wyborach prezydenckich w Serbii w maju 2012 r. jako jedyny Boszniak spośród wszystkich kandydatów.

Jego decyzja o wzięciu udziału w wyścigu do fotela prezydenta wzbudziła zaskoczenie i krytykę ze strony środowisk boszniackich. Przede wszystkim zarzucano $\mathrm{mu}$ - zreszta nie po raz pierwszy - odejście od religii i zbyt duże zaangażowanie się w politykę. Analizując jego pozareligijną działalność można by postawić pytanie, czy jego antyrządowa postawa związana była i jest z rzeczywistymi problemami, z którymi boryka się społeczność Sandżaku, czy też była to próba zafałszowania obrazu w celu odwrócenia uwagi od licznych zarzutów, które były mu stawiane. Można by również postawić pytanie, na ile jego postawa była samodzielna, skoro był częścią instytucji z Bośni i Hercegowiny - państwa, w którym stosunki boszniacko-serbskie dalekie były i są od harmonijnych. Zaskakująca była także decyzja o wzięciu udziału w wyborach prezydenckich oraz odważne stwierdzenia, że nie bierze pod uwagę innej możliwości, jak tylko zwycięstwo. Sam kreował się na kandydata, którego program - adresowany do wszystkich obywateli - miał uratować „Serbię przed krokiem w przepaść”. Zukorlić też jednak prowadził kampanię, wygłaszając przemówienia nie do końca zgodne z tym stanowiskiem. 20 kwietnia 2012 r. odwiedził Frankfurt nad Menem, gdzie spotkał się z diasporą boszniacka - na której głosy w dużej mierze liczył - mieszkająca w Niemczech, i wygłosił na wiecu przemówienie, w którym podkreślał kwestię wolności, jaką mogą się cieszyć tamtejsi Boszniacy w przeciwieństwie do tych z Serbii. Z kolei nie dziwił jego brak zainteresowania porozumieniem w kwestii utworzenia jednolitej instytucji jednoczacej wszystkich muzułmanów w Serbii. Powstanie jej pozbawiłoby go nie tylko stanowiska muftiego, stojącego na czele odrębnej instytucji wyznaniowej, ale odebrałoby mu również możliwość łączenia funkcji religijnej, wiążącej go z Bośnią i Hercegowina, z funkcja polityczną bojownika o prawa Boszniaków, realizowanej na serbskiej scenie politycznej, najpierw poprzez partię, teraz już bezpośrednio jako kandydata na prezydenta ${ }^{63}$.

${ }^{63}$ Muftija Zukorlić kandidat za predsjednika Srbije, „Bošnjaci.net. Web magazin”, 7 IV 2012, http://www.bosnjaci.net/prilog.php?rid=1\&pid=45431 (dostęp 12 IV 2012); Muftija Zukorlić: Vanredno stanje u dijaspori ove dvije sedmice, „Bošnjaci.net. Web magazin”, 23 IV 2012, http://bosnjaci.net/prilog.php?pid=45557; R. Popović, Izmiriću Srbiju sa komšijama, „Danas”, 20 IV 2012, http://www.danas.rs/dodaci/sandzak/izmiricu_srbi- 
M. Zukorlić jest bez wątpienia postacią istotną w sandżackim pejzażu politycznym. Nie jest jednak jedyną osobą publiczną generującą konflikty instytucjonalne i personalne, które faktycznie uniemożliwiają mniejszości boszniackiej wypracowanie relacji zwartej grupy, z powodzeniem wykorzystujacej swoje prawa. Jak pokazują stanowiska polityków, ich partykularne interesy, a nawet prywatne animozje uniemożliwiają współdziałanie. Belgrad z kolei zają pozycję obserwatora, który z jednej strony nie ma możliwości jednostronnej stabilizacji regionu, z drugiej zaś może się wydawać, że zgodnie z tym, co twierdzili sami Boszniacy, serbskie władze nie były zainteresowane silnym frontem muzułmańskim, który mógłby się stać aktywną siłą polityczną.

F. Kladničanin uważał, że istotnym problemem rozbicia politycznego i społecznego wśród Boszniaków był brak dostatecznego pluralizmu politycznego, jednak zważywszy, ile partii, w koalicji lub samodzielnie, miało wziąć udział w wyborach w maju 2012 r. trudno zgodzić się z tą opinią. Sam autor zauważał, że wzrost liczby partii sandżackich jest dobry dla demokracji, co jest prawda, jednak ma także rację stwierdzając, że samym Boszniakom koncentrowanie się tylko na istnieniu nowej partii nie przynosi żadnych korzyści ${ }^{64}$.

W mających odbyć się na początku maja 2012 r. wyborach, na płaszczyźnie lokalnej z obszaru Sandżaku konkurować będą ze sobą aż cztery reprezentacje polityczne: koalicja Europejski Nowy Pazar, w skład której wchodzą SDPSSDP-DS-SZS ${ }^{65}$; „Wspólnie dla Nowego Pazaru” - SPS-SRS-JS-PUPS ${ }^{66}$; trzecia

ju_sa_komsijama.42.html?news_id=238642 (dostęp 23 IV 2012); S. Novosel, Muftija Zukorlić kandidat za predsednika Srbije, „Danas”, 12 IV 2012, http://www.danas.rs/dodaci/ sandzak/muftija_zukorlic_kandidat_za_predsednika_srbije.42.html?news_id=238095 (dostęp 15 IV 2012).

${ }^{64}$ F. Kladničanin, Šta treba Sandžaku?, „Danas”, 5 VII 2011, http://www.danas.rs/ danasrs/dijalog/sta_treba_sandzaku.46.html?news_id=218860 (dostęp 13 XII 2011).

${ }^{65}$ SDPS - Socjaldemokratyczna Partia Serbii R. Ljajicia, SDP - Sandżacka Partia Demokratyczna, której przywódca był Ljajić, aktualnie przewodzi jej R. Hodžić, DS - Partia Demokratyczna B. Tadicia, SZS - Partia dla Sandżaku, którą reprezentuje F. Murić. Списак брисаних ПО, Министарство за људска и мањинска права, државну управу и локалну самоуправу, http://www.drzavnauprava.gov.rs/article.php?id=785 (dostęp 17 IV 2012); Регистар ПС, Министарство за људска и мањинска права, државну управу и локалну самоуправу, http://www.drzavnauprava.gov.rs/article.php?id=784 (dostęp 17 IV 2012).

${ }^{66}$ SPS - Socjalistyczna Partia Serbii ówczesnego wicepremiera i ministra spraw wewnętrznych Ivicy Dačicia, SRS - Serbska Partia Radykalna z symbolicznym przywództwem sądzonego w Hadze Vojislava Šešelja, JS - Jednolita Serbia przedsiębiorcy Dragana Markovicia „Palmy”, PUPS - Partia Zjednoczonych Emerytów Serbii Jovana Krkobabicia. Списак брисаних ПО...; Регистар ПС... 
koalicja to SNP-URS ${ }^{67}$, czwarta to „Wszyscy razem” - BDZ ${ }^{68}$. Oprócz czterech koalicji w wyborach wezmą udział ugrupowania znanych aktorów sandżackiej i ogólnoserbskiej sceny politycznej ${ }^{69}$.

${ }^{67}$ SNP M. Đerleka, URS - Unia Romów Serbii z Marko Stevanoviciem na czele. Списак брисаних ПО...; Регистар ПС...

${ }_{68}$ BDZ - Boszniacka Wspólnota Demokratyczna E. Elficia. Списак брисаних ПО...; Регистар ПС...

${ }^{69}$ SDA Sandżaku - Partia Akcji Demokratycznej Sandżaku S. Ugljanina, RS - Reformatorzy Sandżaku Zekiriji Dugopoljaca, DSP - Demokratyczna Partia Sandżaku Zulkefila Sadovicia, SA - Sandżacka Alternatywa Tarika Imamovicia, BDSS - Boszniacko-Demokratyczna Partia Sandżaku; SRP - Sandżacko-Raszka Partia Ismeta Avdulovicia, NPS - Narodowy Ruch Sandżaku Džemaila Suljevicia. Списак брисаних ПО; Регистар ПС... 